\title{
DROSERA SPATULATA VAR. GYMPIENSIS: THE FORMAL DESCRIPTION OF THE "HAIRY SEPAL" TAXON FROM SOUTH-EASTERN QUEENSLAND
}

\author{
ROBERT GIBSON • PO Box $1330 \bullet$ Dubbo, New South Wales, $2830 \bullet$ Australia \\ IVAN SNYDER • 110 Meyer Court • Hermosa Beach, California $90254 \bullet$ USA
}

Keywords: new taxa, observations: Drosera spatulata, Queensland (Australia).

\section{Introduction}

Since the publication of Adrian Slack's first book in 1980 the world has become aware of morphological variation within Drosera spatulata throughout its geographical range. One novel variant that made a dramatic entrance into the horticultural world has short scapes less than $10 \mathrm{~cm}$ tall, which end in a congested raceme of large pink-petalled flowers. The peduncle, pedicels and sepals are conspicuously covered with pilose white hairs. This taxon has informally been known as the "hairy sepal form" and very little has been published about it, particularly its ecological niche. This article is intended to at least partially address this data gap with a formal description of this variant and observations of it in the wild.

\section{Latin Description and Specimens Examined}

Drosera spatulata Labill. Var. gympiensis R. Gibson \& I. Snyder var. nova.

Affin. D. spatulata Labill., sed inflorescentia breviore, 2-8(13) cm longa, floribus 2-13, pedunculo, pedicellis, et sepalis glanduloso-pilosis.

Holotype: Opposite the south end of Fraser Island, Queensland, in swampy soil; wallam community; sea level, 18 January 1928, Anon. 4 [AQ183256].

Paratype: $25 \mathrm{~km}$ NE of Gympie, along Tin Can Bay Road, Queensland, 6 March 2004, $R$. Gibson \& K. Hirsch 130 [BRI, NSW].

\section{Description}

Drosera spatulata var. gympiensis differs from the typical form of $D$. spatulata, with which it grows sympatrically, primarily in scape characters (whose characters, where they differ, are provided in parentheses), in the following ways: Herb with fibrous roots to $0.2 \mathrm{~mm}$ diameter. Stem very short. Leaves crowded in a flat rosette 12 to $25 \mathrm{~mm}$ diameter; lamina spathulate, narrowed, flat petiole, the whole 5-12 $\mathrm{mm}$ long by 2-3 $\mathrm{mm}$ wide, the under surface with appressed white eglandular hairs; stipules three-lobed, the central lobe broadly triangular with the free lobe to $1 \mathrm{~mm}$ long, the adjacent lobes narrowly triangular, to $3 \mathrm{~mm}$ long (see Figure 1, and Back Cover). Inflorescences (0-) 1-4, racemose, 1-sided, 2-4 (-8) cm long (2-30 cm long) with 3-6 (-13) flowers (2-20 flowers). Peduncle base eglandular pilose with white hairs $0.2 \mathrm{~mm}$ long above a sparse cover of white stalked eglandular hairs $0.04 \mathrm{~mm}$ long (almost glabrous with scattered glandular hairs to $0.05 \mathrm{~mm}$ long); upper peduncle, pedicels and sepals glandular and eglandular pilose with both glandular and eglandular white hairs 0.3-1.0 mm long above a sparse cover of white hairs $0.04 \mathrm{~mm}$ long (with a sparse cover of glandular and eglandular hair to $0.05 \mathrm{~mm}$ long). Bracts subulate to $1.6 \mathrm{~mm}$ long with a few glandular hairs to $0.3 \mathrm{~mm}$ long at the base, the remainder of the surface with a moderate cover of white eglandular hairs to $0.04 \mathrm{~mm}$ long (subulate to $1.5 \mathrm{~mm}$ long, with scattered scabrous eglandular hairs to $0.04 \mathrm{~mm}$ long). Pedicels terete 1.2-3.0 mm long (1.2-2.0 mm long). Calyx narrow ovate to narrow obovate, $3.0-3.6 \mathrm{~mm}$ long, (elliptic to narrow obovate, $2.0-2.5 \mathrm{~mm}$ long). Petals obovate, dark pink, $5 \mathrm{~mm}$ long $\times 3 \mathrm{~mm}$ wide (pale pink, $3.2 \mathrm{~mm}$ long $\times 2 \mathrm{~mm}$ wide) (see Figure 2). Styles 


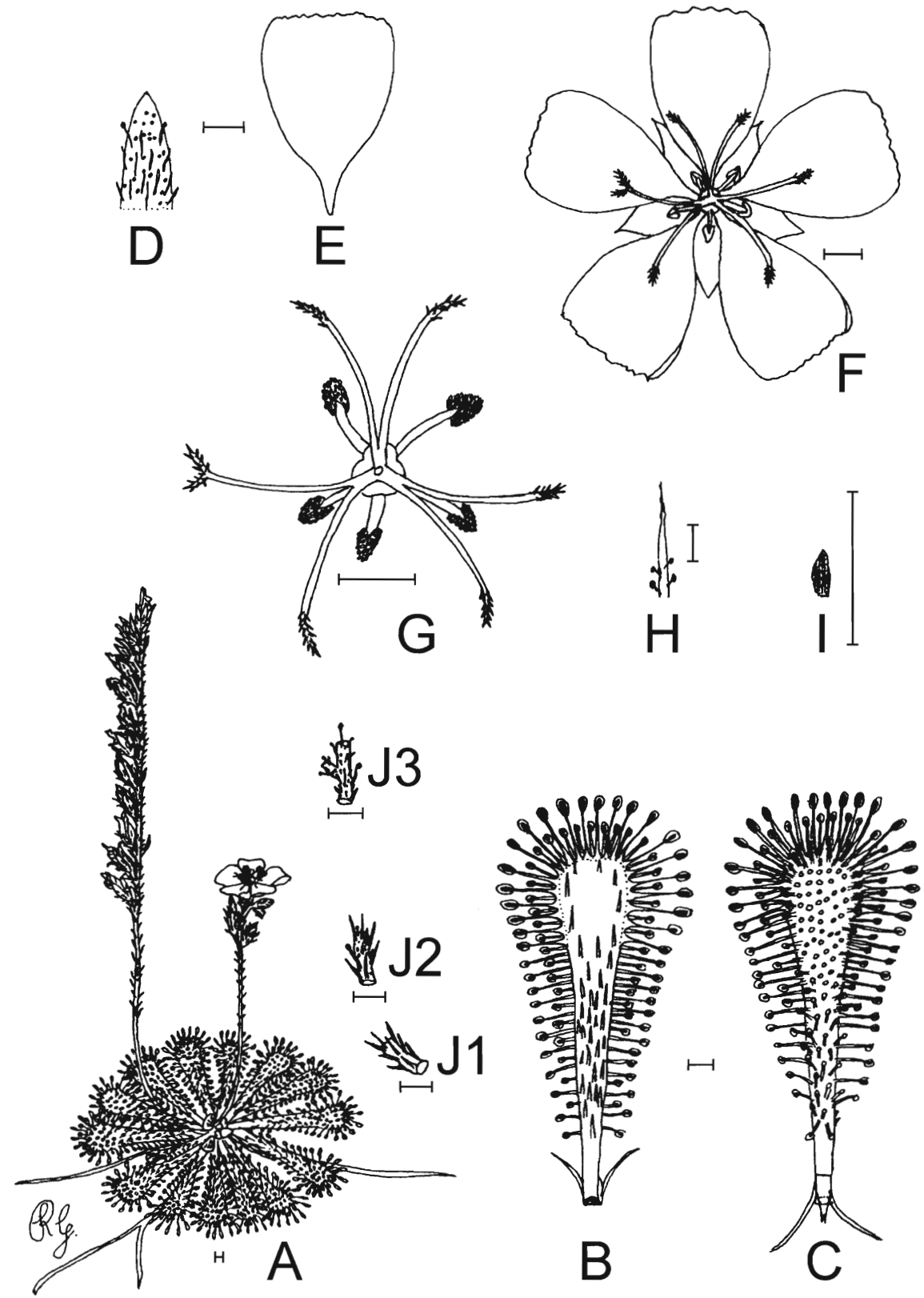

Figure 1: Line drawing of Drosera spatulata var. gympiensis. (A) Whole plant in flower showing the thick roots, (B) leaf under-surface showing appressed hairs, (C) leaf upper surface with the stipule pulled back, (D) free portion of the sepal with short and longstalked glandular hairs, (E) detached petal, (F) open flower, (G) detail of the ovary, styles and stamens - note the rare bifid style apex, $(\mathrm{H})$ bract, (I) ovoid seed and (J1-3) detail of the peduncle surface, $\mathrm{J} 1$ = peduncle base, $\mathrm{J} 2$ = peduncle below the inflorescence and J3 = peduncle amongst the flowers with a pedicel). Illustration by R. Gibson, June 1999. The scale bar represents $1 \mathrm{~mm}$ in all cases. Note the sepal apices in (F) vary in appearance due to the differing degrees that the tips reflex at anthesis. In $D$. spatulata it is typical for some sepal tips to remain reflexed in fruit. 


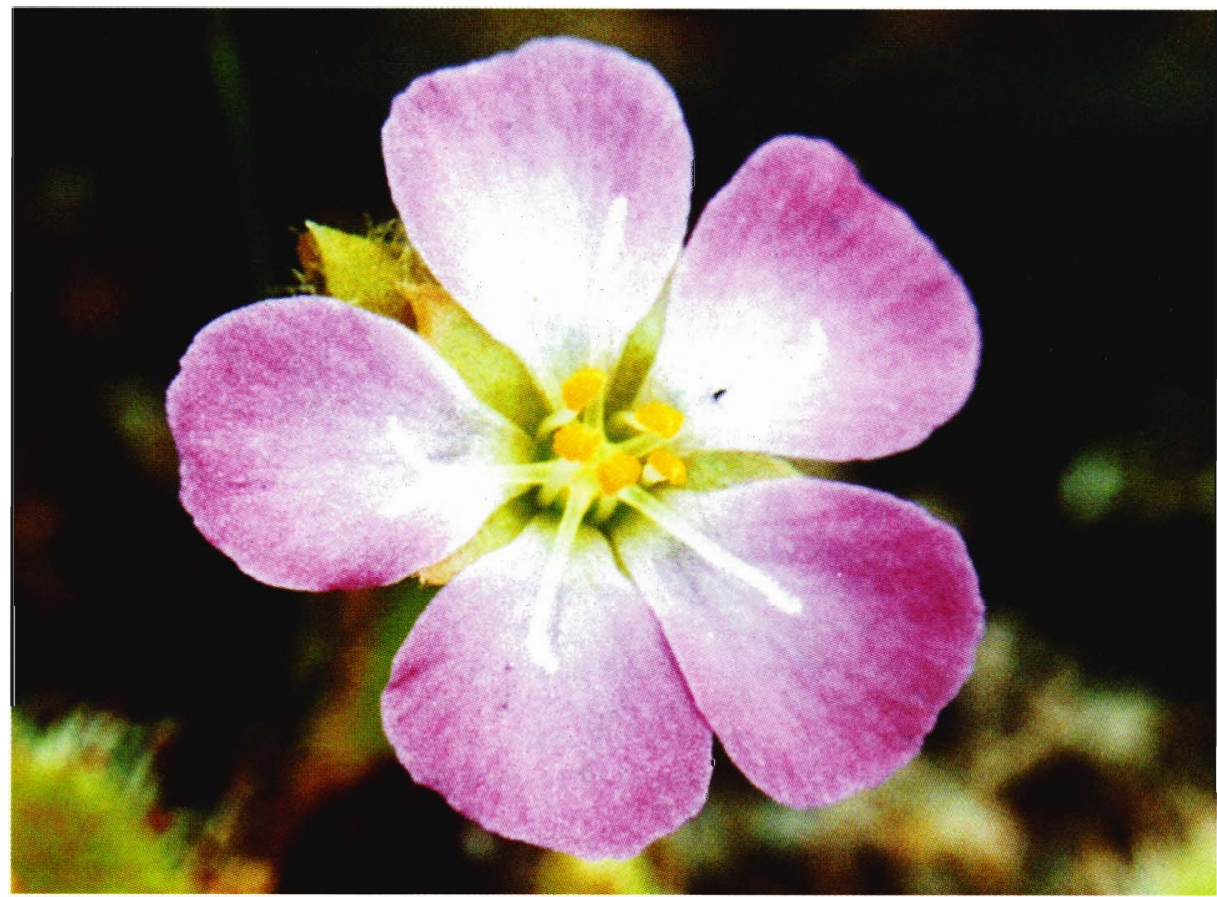

Figure 2: Close up of the open flower of $D$. spatulata var. gympiensis in cultivation. Note the dark pink colour of the petals.

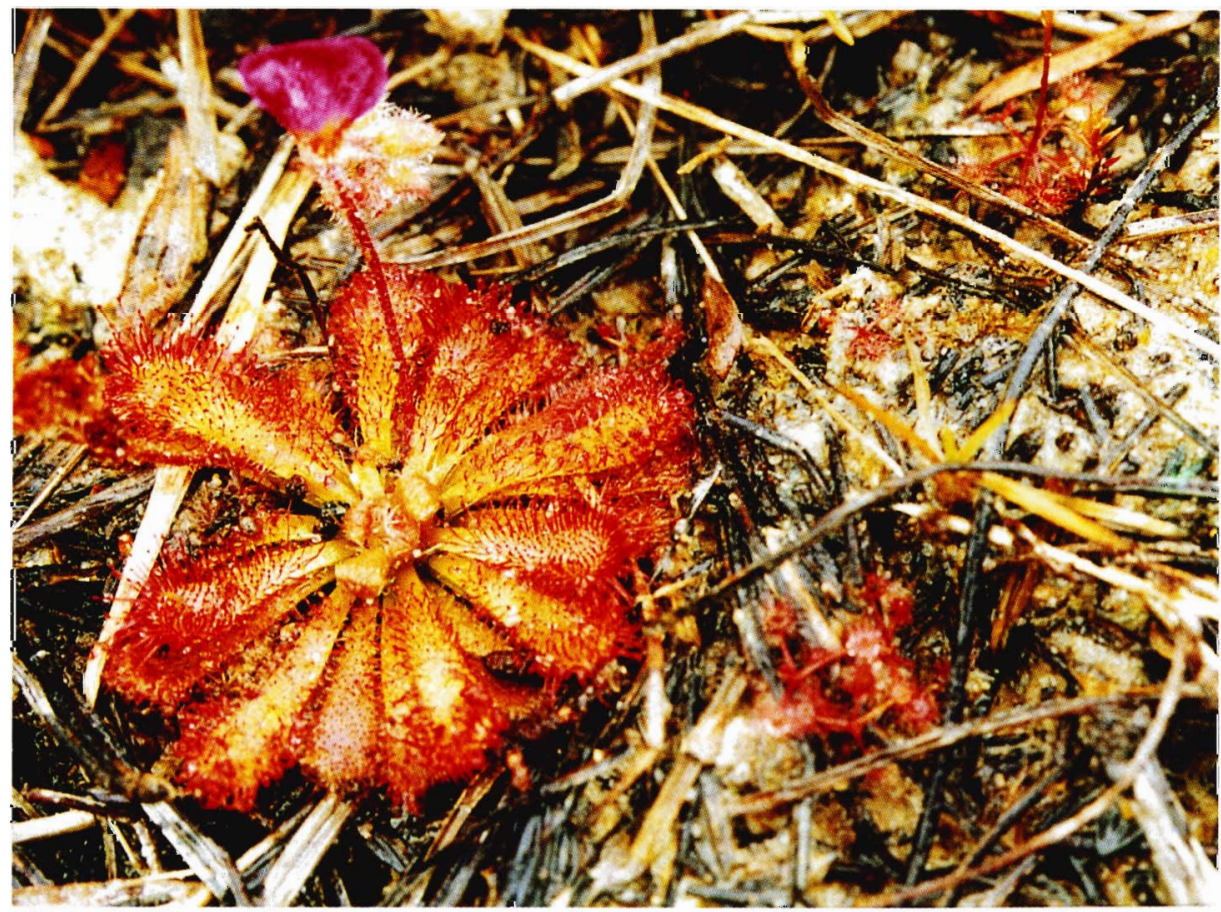

Figure 3: Plant of $D$. spatulata var. gympiensis in the wild, near Gympie. Note the white pilose hairs on the apex of the inflorescence. The sundews to the right are a form of $D$. peltata. The plants were photographed in early April. 
3, bipartite to the base. Style segments, green to pink, 2-2.5 mm long, terete; the apex rarely bifurcated. Stigmas $0.5 \mathrm{~mm}$ long, minutely papillose. Seeds ellipsoid-cylindrical, black $0.4 \mathrm{~mm}$ long by 0.1-0.12 mm maximum diameter (black-dark brown, narrow ellipsoid-obovoid, $0.4 \mathrm{~mm}$ long by 0.06-0.08 mm maximum diameter). (See Figure 1.)

\section{Distribution}

Drosera spatulata var. gympiensis appears to have a limited natural range, found in south eastern Queensland north east of the city of Gympie where one of us (RG) has studied this taxon. The here-designated type specimen was collected about $40 \mathrm{~km}$ to the north, but D. spatulata var. gympiensis has not been found around the nearby city of Maryborough (150 km north of Gympie (B. Pierson, pers. comm. March 1999) and to date has not been collected in coastal wetlands south east of Gympie, where it could occur. In contrast the typical form of D. spatulata, informally called the "Kanto" type by Slack (1980), grows sympatrically with D. spatulata var. gympiensis, and is also found along the entire eastern Australian seaboard, and adjacent ranges and throughout Tasmania (Marchant and George, 1982). It also occurs along the western margin of the Pacific Ocean north from New Guinea to southern Japan (Slack, 1980).

\section{Habitat}

Drosera spatulata var. gympiensis grows in coastal and near coastal wetlands near the city of Gympie in South Eastern Queensland [26.10 ${ }^{\circ}$; $152.32^{\circ} \mathrm{E}$ ]. One of us (R.G.) observed this variant in damp clay soil on the edge of a slash pine (Pinus elliottii) plantation and also in heathland along a nearby creek (see Figure 3). The plants were locally abundant in any one area and grew sympatrically with $D$. burmannii, $D$. peltata and the typical morphotype of $D$. spatulata. The two forms of D. spatulata were instantly recognisable and separable by their scapes. The typical taxon has virtually hairless scapes up to $30 \mathrm{~cm}$ tall with usually more than ten flowers. No intergrades were observed.

\section{Discussion}

The hairy sepal variant has become well known in cultivation over the last 15 years however it is poorly known in the wild. There have been few herbarium collections, of which the oldest I (R.G.) have seen was collected in January 1928 from the mainland Australia coast opposite Fraser Island (Anon. 4 [AQ183256] BRI). This specimen has a short hairy scape with three pink petalled flowers. It was collected in wallam vegetation, a term for coastal heathland in southern Queensland that typically contains species of Banksia (Proteaceae) in the tree and shrub layer. The formal description of Drosera spatulata var. gympiensis is perhaps a bold step. However it appears warranted based on the distinct morphology and genetic isolation of this taxon within this species complex. A formal study of variation within the complex throughout its range is required, and has been given a great start by the detailed cytological work done by Kondo (1971) and by Salmon's (2001) detailed descriptions of variation within D. spatulata in New Zealand. Salmon described four forms of $D$. spatulata but noted that intergrades were found between them. No intergrades have been found between D. spatulata var. gympiensis and the typical form of $D$. spatulata, even though they grow sympatrically. Although, one of us (I.S.) has produced a completely fertile hybrid between these two forms that demonstrates that they are closely related.

Vegetatively Drosera spatulata var. gympiensis is virtually indistinguishable from the typical form of $D$. spatulata. The flower structure and seed morphology and genetic compatibility are also very close. Given these factors it was considered that varietal status of the "hairy sepal form" was the most appropriate taxonomic status. The formal description of this distinctive taxon is hoped to be an important step in the progressive understanding and analysis of variation within $D$. spatulata, and may make it possible to consistently apply taxonomic rank to the other members of this complex. 
I (R.G.) wish to thank the director of The Queensland Herbarium for study access to the collection that provided data for this article. Suggestions from an anonymous reviewer were most appreciated and greatly helped with this paper.

\section{References}

Kondo, K. 1971. A Review of the Drosera spatulata complex. Journ. Jap. Bot. 46: 321-326.

Marchant, N. and George A. S. (1982) Droseraceae in (A. S. George Executive Editor) Flora of Australia 8: 9-66. Australian Government Publishing Service, Canberra.

Salmon, B. 2001. Carnivorous Plants of New Zealand. Ecosphere Publications, Manurewa, New Zealand.

Slack, A. 1980. Carnivorous Plants. Alphabooks, Sherborne, England.

\section{LITERATURE REVIEWS}

Boylan, J.D., Morris, J.E. 2003, Limited Effects of Barley Straw on Algae and Zooplankton in a Midwestern Pond. Lake and Reservoir Management. 19(3): 265-271.

The investigators explored the usefulness of straw from barley (presumably $\times$ Elyhordeum) as an aquatic mulch. Other researchers have claimed that barley can be used to control planktonic and filamentous algae. Using a set of replicated tests, the researchers attempted to demonstrate the effectiveness of barley straw but were unable to find consistent, useful effects. They concluded that, however, their inability to see such effects might have been the result of low oxygen levels in the decomposing straw, and that increasing the oxygen levels might facilitate beneficial attributes of the barley straw. Carnivorous plant growers attempting to cultivate Aldrovanda and aquatic Utricularia often bemoan the adverse effects of filamentous algae. Barley straw, in a properly oxygenated environment, might have value for the cultivation of these difficult aquatic species; such horticulturists are encouraged to read this paper and the papers cited therein. (BR)

Casper, S.J. 2004. Pinguicula louisii Markgraf (Lentibulariaceae) in Albania. Short Notice about a Nearly Unknown and Perhaps Neglected Butterwort. Haussknechtia 10: 239-245.

This paper provides new insight into an Albanian member of the taxonomically difficult $P$. crystallina group. The Albanian plants show "rounded corolla lobes" of the lower lip (vs. more or less emarginate ones in other populations) and a "long spur" (as long as or longer than the rest of the corolla). In addition, the lobes of the lower calyx lip are "nearly undivided and not spreading". The author revised material recently collected near the type locality of $P$. louisii as $P$. hirtiflora var. louisii (i.e. he does not follow the practice to include P. hirtiflora in P. crystallina). (JS)

Casper, S.J. and Stimper, R. 2004. Chromosome Numbers in the Pinguicula crystallina-hirtiflora Aggregate - a Preliminary Note. Haussknechtia 10: 247-251.

All investigated specimens (from Italy, Cyprus and Albania) had $2 \mathrm{n}=28$ chromosomes. (JS)

Casper, S.J. 2004. Two New Pinguicula Species (Lentibulariaceae; P. benedicta group) from the Eastern Mountain Range of Cuba (Greater Antilles) with Reddish Flowers. Wulfenia 11: 1-13 (2004).

Pinguicula bissei and $P$. caryophyllacea are closely related to the rather variable $P$. benedicta. Both new species (each only known from the respective type collections) differ from $P$. benedicta by their pink or red-violet (or rarely white) corollas, while $P$. benedicta is said to be characterized by blue or blue-violet flowers. Pinguicula bissei has narrowly oblong, divergent and non-overlapping lower corolla lobes, $P$. caryophyllacea has oblong to obovate lower corolla lobes that tend to overlap in most specimens. (JS) 


\title{
CARNIVOROUS
}

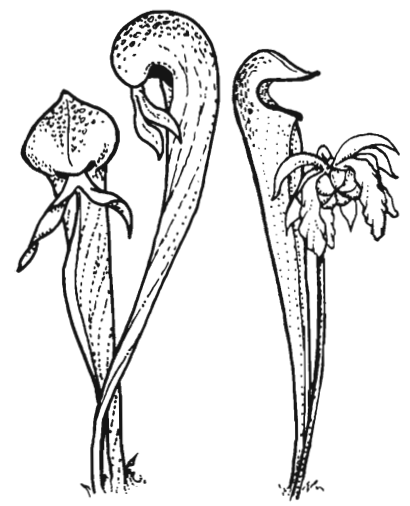

\section{PLANT \\ NEWSLETTER \\ Journal of the International \\ Carnivorous Plant Society \\ www.carnivorousplants.org}

Volume 34, Number 2 June 2005

Front Cover: A large plant of Nepenthes rowanae in a swamp on Cape York, with upper, intermediate and lower pitchers. The largest pitchers on this specimen were about $20 \mathrm{~cm}$ in height (not including the lid). See article on page 36. Photograph by Charles Clarke.

Back Cover: A robust plant of $D$. spatulata var. gympiensis with the tallest scape seen during fieldwork. Beside it, and behind it are $D$. burmannii rosettes. Note the clay soil in which the sundews are growing. See article on page 56 . Photograph by Robert Gibson.

Carnivorous Plant Newsletter is dedicated to spreading knowledge and news related to camivorous plants. Reader contributions are essential for this mission to be successful. Do not hesitate to contact the editors with information about your plants, conservation projects, field trips, or noteworthy events. Contributors should review the "Instructions to Authors" printed in the March issue of each year. Advertisers should contact the editors.Views expressed in this publication are those of the authors, not the editorial staff.

All correspondence regarding dues, address changes and missing issues should be sent to the Membership Coordinator at the ICPS. Do not send such correspondence to the editors. Checks for subscriptions and back issues should be made to the ICPS in US funds. Dues for 2005 are $\$ 25$.

\author{
ICPS, Inc. \\ PMB 322 \\ 1564-A Fitzgerald Drive \\ Pinole, CA 94564-2229, USA \\ icps@carnivorousplants.org
}

\section{President \\ Vice President \\ Carl Mazur, email: carl@carnivorousplants.org \\ Treasurer \\ Cindy Slezak, email: cindy@carnivorousplants.org \\ Secretary, Seed Bank \\ Richard Myers, email: richard@ carnivorousplants.org \\ Board Member \\ John Brittnacher, email: john@ carnivorousplants.org. seedbank listed in this issue. \\ Chris Teichreb, email: chris@ carnivorousplants.org \\ Board Member \\ Steve LaWarre, email: stevel@ camilorousplants.org}

Editors:

Barry A. Rice, P.O. Box 72741, Davis, CA 95617, USA. email: barry@ camivorousplants.org

Jan Schlauer, Zwischenstr. 11, D-60594 Frankfurt, Germany, email: jan@ camivorousplants.org

Page Layout: Steve Baker, email: steve@carnivorousplants.org

Date of effective publication of the March 2005 issue of Camivorous Plant Newsletter: 9 March 2005.

The ICPS is the International Cultivar Registration Authority (ICRA) for cultivated carnivorous plants according to The International Code For The Nomenclature of Cultivated Plants. Send relevant correspondence to the ICPS, Inc.

PUBLISHER: ICPS, Inc., Pinole, California. Published quarterly with one volume annually. Desktop Publishing: Steve Baker, 5612 Creek Point Drive, Hickory, NC 28601. Printer: Kandid Litho. Logo and masthead art: Paul Milauskas. Dues: \$25.00 annually. @ 2005 Carnivorous Plant Newsletter. All rights reserved. ISSN \#0190-9215. 